\title{
Identification of Compensation System in Culinary Business: The Case of Bogor City, West Java Province, Indonesia
}

\author{
Lindawati Kartika \\ Department of Management \\ IPB University (Bogor Agricultural University) \\ Bogor, Indonesia \\ linda@apps.ipb.ac.id
}

\author{
Dikky Indrawan * \\ School of Business, \\ IPB University (Bogor Agricultural University) \\ Bogor, Indonesia \\ rdikky@apps.ipb.ac.id
}

\begin{abstract}
The objective of this research is to identify the Compensation System for Small Medium Enterprise (SME) in the culinary business at Bogor City, West Java Province. The subjects of this study were 24 SME in the culinary business. Data collection used primary and secondary data through questionnaires, observation, in-depth interviews, and literature studies. The results show that the average salary for the entry-level starts from above IDR 1.8 million until above IDR 5.1 million for top management level for SME in the culinary business in Bogor City. Most salaries were below the regulated minimum wages. Two out of ten compensable factors affected the job value, namely formal education and human relation skill.
\end{abstract}

Keywords: base pay, culinary business, small medium enterprises, Hay system, Eckenrode method

\section{INTRODUCTION}

One of the businesses that develop along with the development of the tourism sector in Bogor refers to the culinary-based small and medium enterprises in the form of restaurants or cafes. Bogor takes a second rank for the largest number of restaurants in West Java after Bandung. This case demonstrates that Bogor has great potential in the culinary business. The great potential of culinary cluster in Bogor should be put in good use. ot only quantity but the welfare improvement of human resources in this culinary business should also be noted. It highlights the realization of Decent Work or commonly known as job eligibility. This effort is consistent with Sustainable Development Goals (SDGs) number 8, which contains efforts to promote sustainable and inclusive economic growth, productive and comprehensive opportunities, and decent work for all [1].

However, in 2019, there are still many businesses, mainly small and medium enterprises, that have not implemented a wage system that refers to the minimum wage set by the Government. Wage or salary is a form of financial compensation directly given to the employee in a production process. The amount of wages is influenced by Government Regulations regarding minimum wages, either through Provincial Minimum Wages (UMP) or Regency Minimum Wages (UMK). This stipulation aims to keep employees' wages in balance and not go further below the poverty line because minimum wages play an important role in reducing wage inequality in Indonesia [2]. The minimum wage affects the wages of employees and finally increases the sectoral wages, especially the formal sector [3, 4].

In addition to the importance of minimum wages as the external environmental element for the basis of compensation stipulation, the internal environmental element that consists of organizational policies and the organizational ability to pay the salaries for its employees also plays an important role in stipulating the compensation [5]. One of the causes of employees' dissatisfaction is their salary [6]. An appropriate and fair salary will make employees feel valued for the work they have done. One consequence of an inappropriate compensation system at the company is the emergence of employee turnover intentions, which can impact on the company's turnover. The intention of turnover is the desire of employees to quit the organization that provides them monetary wages or income [7]. A high turnover rate will create a negative impact on the organization, produce instability and uncertainty in labor conditions [8]. Employee turnover retention is the way to solve the employee turnover. The retention refers to the definition of holding, maintaining, continuing, and preventing it from leaving [9]. Therefore, employee retention can be seen as a way or a company strategy to retain its employees.

Employee payroll conditions, which are still under the minimum wages of Bogor, especially for the culinary business (restaurant or café), are supposed to have further impacts on employee turnover problems. An inappropriate compensation stipulation may lead to injustice that produces low job satisfaction. Therefore, the culinary business in Bogor needs an appropriate compensation system. This study is conducted to identify the financial compensation system of the culinary business in Bogor. The study aimed s to identify the employees' salary system for the culinary business in Bogor.

\section{MATERIALS AND METHODS}

\section{A. Sample and data collection}

This study conducted from January until February 2019, which involved 24 SME in culinary business consisting of restaurants and café located in Bogor City. Primary data obtained from the survey results on employee's salaries in 
d. Human Relation Skill. Human relation skill functions to measure the extent to which jobholders interact with others. Jobs that involve the interpersonal interacts are valued at s higher level compared to those who do not have these requirements [15].

questionnaire carried out to find out the key factors of work. It used a ranking scale, where the respondents were asked to rank the objects relatively [10]. In addition, unstructured interview techniques were also conducted to find out the compensable factor. The secondary data contained a general description of the culinary-based business in Bogor, literature books, and journals that are relevant to the research.

The sampling method used in this study was nonprobability sampling with a purposive sampling technique. Purposive sampling technique is a technique with certain considerations or criteria [11] to determine the experts in ranking the compensable factors. There were 565 respondents from 24 culinary businesses in Bogor. Furthermore, the judgment sampling was performed in selecting the experts as the respondents of the study [11]. The selected experts were the Owner of Culinary business, Store Manager, and Academics in the field of human resource management.

\section{B. Data Analysis}

Data processing and data analysis used the descriptive statistical analysis, compensable factors analysis based on the Hay system concept, Point System, and Eckenrode method. Descriptive statistics used to analyze data through the description of the collected data in order to make a general conclusion [12].

In a point system, the assessors allocated numerical values for certain occupational factors, and the total value will provide a quantitative assessment of the relative value of the work [13]. The stages of conducting the point system method were:

1. Selecting the group of work.

Several levels of job titles were grouped into job grades.

The average restaurant and café in Bogor had several position levels or grades.

2. Identifying the compensable factors. The method used for the compensable factors was the Hay System. It divided the compensation factors into three parts, namely know-how, problem-solving, and accountability.

a. Formal Education This factor used to assess the lowest level of education in a company to carry out certain job tasks [14].

b. Job Experience. This factor used to assess the lowest level of job experiences owned by the employees.

c. Managerial Skills. This factor is used to qualify the jobs that have various functions or tasks considered as more complex tasks and jobs that only have specific functions. Consequently, the higher complexity and the stronger managerial skill is necessary to complete the tasks given to the employees [15].

3. Determining the factor weight

The level of factors was determined using the opinions of experts. The method used in determining factor weight was the Eckenrode method. This method was a weighting method used to determine the degree of importance or weight of each criterion specified in decision-making [19]. The weight value was important because it may affect the final total value. This weighting method was carried out by changing the sequence into values such as sequence one into the highest level (value) and sequence five into the lowest level (value). The steps in the calculation using the Eckenrode method were as follows:

a. deciding the work factor,

b. determine the weight of the work factor by giving score for the answers, the first list will be multiplied with the value obtained by reducing the factors and sequence,

c. The sequence value previously obtained from the experts is multiplied by the value of the multiplier,

d. determining the minimum points, maximum points and then the interval,

e. specifying the job value and

f. the value of each point is obtained by dividing the total incentives with total points. 


\section{RESULTS}

\section{A. General Overview of Salary Distribution in the Culinary Business in Bogor}

Fig. 1 shows the comparison of the average salary of employees at restaurants in Bogor with the regency minimum wage of Bogor and Provincial minimum wage of West Java in 2019. Salary stipulation in most culinary businesses in Bogor still did not refer to the provincial minimum wage or the regency minimum wage. Only 16 out of 24 business $(33.33 \%)$ met the provincial minimum wage of West Java. None of these businesses met the regency minimum wage of Bogor in 2019 (see Fig. 1).

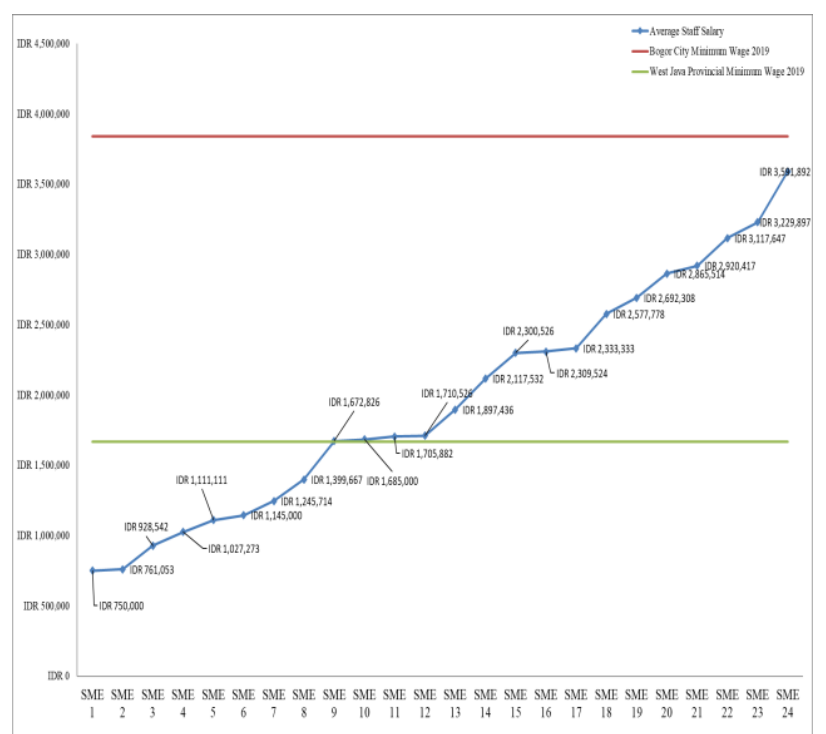

Fig 1. Comparison of the average income of the culinary business staff in Bogor to the Minimum Wages of Bogor and West Java.

Most of the 24 restaurants and cafes had around 34 employees. We identified 13 (thirteen) type of position in the culinary-based businesses. Table 1 shows these 13 jobs with a salary that represents the average, minimum, and maximum. The highest position in restaurant or coffee in Bogor was general manager or restaurant manager with an average salary up to IDR 5,108,889. Meanwhile, other position salaries were under the minimum wages of Bogor regency, such as Finance \& Accounting Staff, Logistic Staff, Captain / Head of Waiter, Marketing \& IT Staff, Admin, Cooking staff, Barista, Dish Washer, Helper, Cashier and Waiter is still under the minimum wages. The lowest wage received by the waiters (IDR 420,000), while the highest wage received by Head Chef (IDR 13,000,000).

TABLE 1. SALARY SURVEY RESULT BASED ON 24 CULINARY SME'S FOR 13 CRITICAL POSITIONS (INDONESIAN RUPIAH)

\begin{tabular}{|c|c|c|c|c|c|}
\hline No & Job Title & $\begin{array}{c}\text { Total } \\
\text { Person }\end{array}$ & $\begin{array}{c}\text { Average } \\
\text { Salary }\end{array}$ & $\begin{array}{c}\text { Minimum } \\
\text { Salary }\end{array}$ & $\begin{array}{c}\text { Maximum } \\
\text { Salary }\end{array}$ \\
\hline $\begin{array}{c}\text { General } \\
\text { Manager/ } \\
\text { Restaurant } \\
\text { Manager }\end{array}$ & 35 & $5,108,889$ & $2,000,000$ & $12,000,000$ \\
\hline 2 & Head of Chef & 21 & $4,657,929$ & $1,200,000$ & $13,000,000$ \\
\hline
\end{tabular}

\begin{tabular}{|c|c|c|c|c|c|}
\hline 3 & $\begin{array}{c}\text { Finance \& } \\
\text { Accounting } \\
\text { Staff }\end{array}$ & 15 & $3,502,029$ & $2,000,000$ & $6,100,000$ \\
\hline 4 & Logistic Staff & 33 & $3,217,738$ & 720,000 & $6,883,418$ \\
\hline 5 & $\begin{array}{c}\text { Captain / } \\
\text { Head of } \\
\text { Waiter }\end{array}$ & 19 & $3,052,117$ & $1,100,000$ & $4,902,500$ \\
\hline 6 & $\begin{array}{c}\text { Marketing \& } \\
\text { IT Staff }\end{array}$ & 12 & $2,461,667$ & 840,000 & $4,700,000$ \\
\hline 7 & Admin & 5 & $2,367,420$ & $2,100,000$ & $3,437,100$ \\
\hline 8 & Cooking staff & 149 & $2,337,829$ & 690,000 & $6,605,612$ \\
\hline 9 & Barista & 36 & $2,254,575$ & 750,000 & $4,500,000$ \\
\hline 10 & Dish Washer & 16 & $2,064,413$ & $1,300,000$ & $2,800,000$ \\
\hline 11 & Helper & 96 & $1,897,010$ & 900,000 & $3,500,000$ \\
\hline 12 & Cashier & 19 & $1,837,158$ & 750,000 & $3,201,800$ \\
\hline 13 & Waiter & 109 & $1,531,431$ & 420,000 & $3,500,000$ \\
\hline & $\begin{array}{c}\text { Total } \\
\text { Employees }\end{array}$ & 565 & & & \\
\hline
\end{tabular}

\section{B. The Result of Compensable Factors using the Hay Method}

We found the factors of compensation in Bogor culinary business. Based on the collected data of know-how, problemsolving, and accountability for 24 culinary business, we clustered the findings and weighted the compensable factors using Eckenrode system method (Table 2). We found the biggest weight belonged to the formal education factor with a percentage of 18.7, whereas the thinking challenge became the smallest one with a percentage of 7.41. The results indicated that formal education was the main aspect of employee recruitment, especially in the culinary business in Bogor.

TABLE 2. ECKENRODE SYSTEM TABLE FOR BUSINESS BASED ON CULINARY AT BOGOR CITY

\begin{tabular}{|c|c|c|c|c|c|c|c|}
\hline \multirow{2}{*}{ Subfactors } & \multirow{2}{*}{ Weight } & \multicolumn{5}{|c|}{ Level } & \multirow{2}{*}{$\begin{array}{c}\text { Inte } \\
\text { rval }\end{array}$} \\
\cline { 3 - 8 } & & $\mathbf{1}$ & $\mathbf{2}$ & $\mathbf{3}$ & $\mathbf{4}$ & $\mathbf{5}$ & \\
\hline Formal Education & 0.1870 & 1 & 6 & 10 & 14 & 18 & 42 \\
& & 9 & 1 & 3 & 5 & 7 & \\
\hline Job experiences & 0.0949 & 9 & 3 & 52 & 74 & 95 & 21 \\
\hline Managerial Skill & 0.0862 & 9 & 2 & 47 & 67 & 86 & 19 \\
\hline Human Relations & 0.1430 & 1 & 7 & 14 & - & - & 64 \\
\hline Skills & & 4 & 9 & 3 & & & \\
\hline Creativity & 0.0828 & 8 & 4 & 83 & - & - & 37 \\
\hline Physical efforts & 0.0741 & 7 & 3 & 52 & 74 & - & 22 \\
\hline Responsibility & 0.0803 & 8 & 2 & 44 & 62 & 80 & 18 \\
\hline Risk of Job & 0.0783 & 8 & 3 & 55 & 78 & - & 23 \\
\hline Asset Liability & 0.0934 & 9 & 3 & 65 & 93 & - & 28 \\
\hline Decision Making & 0.0811 & 8 & 4 & 81 & - & - & 36 \\
\hline
\end{tabular}




\section{DISCUSSION}

Although the culinary business is having good growth in Bogor, the compensation for their workers was not following the regulated minimum wage. It shows that many culinary businesses did not comply with government regulations to provide better compensation. It implies that the workers were not meet the standard welfare to live as a human in Bogor and decent work for all [1, 2]. Moreover, it indicated that the job seeker supply is higher than the demand. This circumstance could create dissatisfaction and increases employee turnover $[6,7,8]$.

The culinary business in Bogor valued education and followed by human relation skills as the important compensable reason to pay their workers [14, 15]. Other capabilities were not even close to these factors. It implies that other factors were not valued to influence the growth of the culinary business in Bogor.

\section{CONCLUSION}

This study concluded that the compensation system in the culinary business was not meet the regional minimum wage. The compensable design was influenced by the value of two compensable factors, namely formal education and human relation skill. Other factors, namely job experiences, managerial skill, creativity, physical efforts, responsibility, risk of the job, asset-liability, and decision making were not important to design workers' salary in the culinary business in Bogor.

\section{REFERENCES}

[1] Yao, C., Parker, J., Arrowsmith, J. and Carr, S., "The living wage as an income range for decent work and life", Employee Relations, Vol. 39 No. 6, pp. 875-887, 2017.

[2] Chun, N., and Khor, N.,. Minimum Wages and Changing Wage Inequality in Indonesia. ADB Economics Working Paper Series 196. Asian Development Bank, Manila, 2010
[3] Hohberg, M., and Lay, J... The Impact of Minimum Wages On Informal and Formal Labor Market Outcomes: Evidence from Indonesia. IZA Journal of Labor \& Development, 4(14): 1-25, 2015.

[4] Alaniz, E., Gindling, T., and Terrell K, “The Impact of Minimum Wages On Wages, Work and Poverty in Nicaragua". IZA Discussion Paper 5702, 2011

[5] Milkovich, G., Newman, J., and Gerhart, J., "Compensation" Eleventh Edition. New York: The McGraw-Hill Companies, Inc., 2014.

[6] Rivai, Veithzal. "Manajemen Sumber Daya Manusia untuk Perusahaan: dari Teori ke Praktik". Jakarta: PT RajaGrafindo Persada. 2008.

[7] Ardiaz, W. S., "Peran Perceived Organizational Support sebagai Moderator Pada Hubungan antara Job Stress dengan Intensi Turnover". Tesis. Yogyakarta: Universitas Gajah Mada., 2015.

[8] Sulistyawati, A. I. and Indrayani, R. A.,. 'Pengaruh Kepuasan Karyawan, Training, Turnover, Dan Produktivitas Karyawan Terhadap Keunggulan Bersaing Melalui Kinerja Perusahaan'. Jurnal Dinamika Akuntansi, 4(2): 88-93., 2012.

[9] Yamamoto, H., 'The Relationship Between Employee Benefit Management And Employee Retention'. The International Journal of Human Resource Management,22(17): 3550-3564, 2011.

[10] Sekaran,. Metode Penelitian untuk Bisnis Jilid 2. Jakarta (ID). Salemba Empat, 2006.

[11] Sugiyono, "Metode Penelitian Kuantitatif, Kualitatif dan R\&D". Bandung (ID). Alfabeta, 2011.

[12] Sugiyono, "Metode Penelitian Kombinasi". Bandung(ID): Alfabeta., 2013.

[13] Mondy, R. W.,. "Manajemen Sumber Daya Manusia”. Jakarta: Erlangga, 2008.

[14] Pandey, J., and Leelashree, M, “A Study On Job Evaluation - Point Factor Analysis In SME's”. Asian Journal Of Research In Business Economis And Management, 2(5):179-239, 2012.

[15] Skenes, C. and Kleiner, B. H.. "The Hay System of Compensation". Management Research News, 26(2): 109-115. 2003.

[16] NHS Staff Council Job Evaluation Group,. "NHS Job Evaluation Handbook: Fouth Edition ". https://www.nhsemployers.org/casestudies-and-resources/2010/02/nhs-job-evaluation-handbook-fourthedition, 2013.

[17] Kartika, L., Jayawinangun, R., and Mangkuprawira, T. S. "Manajemen Kompensasi”. Bogor: IPB Press., 2016..

[18] BBK. Job Evaluation Manual. Accessed : 10 September 2018, 2018.

[19] Maarif, S., and Tanjung, H.. Manajemen Operasi. Jakarta: PT Grasindo, 2003 